\title{
LAKU BATIN
}

\section{Perjalanan Spiritual Nabi Mūsa dan Khiḍir di dalam al-Qur'an}

\author{
Helfi|email: helfibkt@gmail.com \\ IAIN Bukittinggi
}

\begin{abstract}
Abdur Rohman | email: abdurrohman@iaipd-nganjuk.ac.id IAI Pangeran Diponegoro Nganjuk
\end{abstract}

\begin{abstract}
Abstrak
Nabi Mūsa adalah orang terpilih dari bangsa terpilih, Bani Isrā̄ìl. Dia memiliki kelebihan 'dapat berkomunikasi langsung dengan Tuhan', menjadi rasul dan menerima Tawrat. Saat ditanya oleh umatnya, 'siapakah manusia yang paling alim?' dia menjawab 'saya'. Atas keangkuhan itulah Allah menegurnya supaya dia mengikuti laku batin kepada seorang hamba yang berada di tempat bertemunya dua laut. Nabi Mūsa kemudian menemuinya dan berguru kepadanya. Dia diterima sebagai murid dengan syarat tidak bertanya apapun yang dilakukan gurunya. Mūsa mengalami tiga peristiwa besar yang tidak masuk akal yaitu: Khidir melubangi perahu yang ditumpanginya, membunuh anak kecil yang tidak berdosa dan membangun tembok miring tanpa ada orang yang menyuruh atau memberikan upah. Masing-masing dari peristiwa besar tersebut dipertanyakan oleh nabi Mūsa sehingga ia tidak lulus uji.
\end{abstract}

Kata kunci: laku batin, Müsa, Khidir.

\section{Pendahuluan}

Diakui atau tidak, bangsa Isrāīl adalah bangsa istimewa pilihan Tuhan. ${ }^{1}$ Mereka adalah bangsa yang pernah mendapatkan 'transfer' makanan surga dan saat berjalan dinaungi mendung. Kebanyakan nabi dan rasul lahir dari bangsa ini. Bangsa istimewa itu memiliki pemimpin yang istimewa, yaitu nabi Mūsa as.

\footnotetext{
${ }^{1}$ Al-Baqarah [2]:57.
}

Spiritualis, vol. 5, no. 2, September 2019

ISSN: $2442-5907 \mid 208$ 
Kelebihan yang dimiliki oleh nabi Müsa ternyata bukan hanya menjadi pemimpin Isrāìl. Dia dipercaya oleh Allah untuk mengemban amanah menjadi seorang rasul sekaligus membawa ajaran Tawrat. Selain itu ia juga masih punya gelar yang tidak dimiliki oleh nabi manapun, alkalim, ${ }^{2}$ bahkan nabi Muhammad sekalipun.

Semua kelebihan yang dimiliki oleh nabi Mūsa itu ternyata hanyalah cover (ilmu syari'at). Di atas itu masih ada ilmu-ilmu ghaib yang tidak dimengerti olehnya dan Allah memberikan ilmu itu kepada hamba yang terpilih. Hamba itu adalah Khidir, sosok misterius yang tidak disebutkan secara langsung namanya oleh al-Qur'an karena Tuhan tidak ingin hamba istimewa itu viral. Khidir adalah seorang sufi, yang tidak ingin namanya terkenal di dunia. Ia hanya ingin kedekatannya kepada Tuhan saja, bukan ketenaran nama di sisi manusia.

Artikel ini akan membahas tentang laku batin yang dijalani oleh nabi Müsa saat berguru kepada nabi Khidir. Penulis lebih condong memberikan tema laku batin dalam hal ini karena pengembaraan Müsa dalam persoalan ini 'tanpa di dampingi wahyu'. Ia harus sam'an wa tă atan kepada orang yang memiliki keahlian tersebut. Ia harus berjalan jauh menyusuri laut dan perkampungan dengan segala misteri yang ada di dalamnya. Karena ilmu ini didapat dari pengalaman langsung, bukan melalui 'contekan wahyu' atau sekolah, penulis lebih condong menyebutnya dengan istilah 'laku batin' karena sesuai dengan karakteristik orang Jawa saat akan menempuh perjalanan spiritual.

Kata laku diambil dari bahasa Jawa mlaku yang memiliki arti berjalan. Kata ini kemudian identik dengan tirakat (perjalanan spiritual) orang-orang Jawa dengan metode tertentu. Sedangkan kata batin memiliki arti yang sama dengan bahasa Indonesia, yaitu sesuatu yang ada di dalam hati; mengenai jiwa dan perasaan; perkara yang tersembunyi (ghaib, atau tidak kelihatan). ${ }^{3}$

Jika kedua kata ini digabung, maka memiliki arti 'perjalanan spiritual untuk mencari perkara yang masih tersembunyi (ghaib)'. Jadi,

\footnotetext{
${ }^{2}$ Al-Nisā' [4]:164.

3 Tim Pusat Bahasa Departemen Pendidikan Nasional, Kamus Babasa Indonesia. Jakarta: Pusat Bahasa, 2008, 147.
} 
perjalanan yang ditempuh oleh seorang sâlike di dalam hal ini bukan untuk mencari ilmu yang bersifat inderawi, tetapi mencari ilmu batin (ilmu spiritual). Dalam khazanah Jawa ada dua istilah yang membedakan antara ilmu dengan ngelmu. Ilmu dapat diperoleh dengan membaca, penelitian, wejangan dari guru, khutbah, maupun metode lahiriyah lainnya. Sedangkan nglemu hanya dapat diperoleh melalui tirakat (melakukan pencegahan hawa nafsu, dengan puasa, atau mengasingkan diri ke tempat yang jauh, seperti hutan, gunung dan sebagainya).

Penjelasan di atas sebenarnya menunjukkan definisi dan ruang lingkup laku batin, namun muatannya masih secara umum. Laku batin memiliki ruang lingkup yang cukup luas. Sebab laku batin adalah sarana untuk mencapai ilmu batin ${ }^{4}$ atau ilmu ghaib, bukan ilmu syari'at yang tampak secara nyata, empiris-rasionalis.

Dalam khazanah Jawa ada banyak metode laku batin yang dapat dilakukan oleh seseorang, yaitu tapa brata (mengasingkan diri dari tempat keramaian); tapa geni (bertapa untuk menghindari nyala api); tapa ngrame (berada di keramaian akan tetapi menghindari segala bentuk kejadian yang mengarah kepada keinginan nafsu, seperti adanya buah-buahan atau makanan yang menggiurkan, ada uang jatuh, para wanita menyilaukan mata dan sebagainya); tapa kungkum (mengasingkan diri dengan cara merendam sebagian badan di sungai); poso mutih (berpuasa tidak makan makanan kecuali hanya berwarna putih, seperti nasi), dan sebagainya. Semua bentuk laku batin tersebut hanyalah metode demi untuk mencapai ilmu batin, yaitu tersingkapnya tabir ilahi (mukäshafah) untuk meneropong hal-hal ghaib di masa depan.

\section{Laku Batin Nabi Mūsa dan Khị̣ir}

Sebelum masuk ke dalam ayat yang membahas laku batin, terlebih dahulu perlu kirannya disajikan kisah di luar al-Qur'an yang masih memiliki keterkaitan dengan kisah al-Qur'an ini nanti. Ada sebuah riwayat yang cukup panjang dari Bukhāri dan Muslim yang menceritakan bahwa suatu hari nabi Mūsa khutbah di depan kaumnya, Bani Isrāîl, lalu ada

\footnotetext{
${ }^{4}$ Suhardi, Manekung di Puncak Gunung: Jalan Keselamatan Kejawen. Yogyakarta: Gajah Mada University Press, 2018, 123.
} 
yang bertanya 'Ayy al-nās a'lam' (siapakan manusia yang paling alim/berilmu)? Kemudian secara spontan nabi Mūsa menjawab anā (saya). ${ }^{5}$ Jawaban tersebut memberikan kesan 'sombong', seolah-olah hanya dia manusia yang paling pandai.

Jawaban itu juga memberikan kesan bahwa kelebihan ilmu yang dimiliki oleh nabi Mūsa tidak disandarkan kepada Allah, akan tetapi kepada dirinya sendiri. Lalu Allah menegurnya supaya berguru kepada orang yang berada di tempat bertemunya dua laut. Saat itulah ayat ini bercerita tentang pengembaraan nabi Mūsa dalam menyelami laku batin. Allah berfirman di dalam surah al-Kahf [18] ayat 65-78:

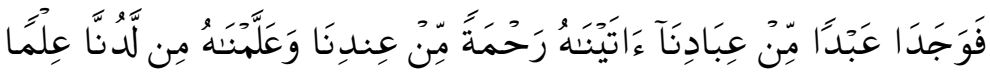

Lalu mereka berdua bertemu dengan seorang hamba di antara hamba-hamba Kami, yang telah Kami berikan rahmat kepadanya dari sisi Kami, dan yang telah Kami ajarkan ilmu kepadanya dari sisi Kami. ${ }^{6}$

Al-Qur'an tidak menyebutkan nama Khidir. Al-Qur'an hanya menyebutkan seorang hamba dari hamba Kami yang diberi rahmat dan ilmu laduni. Mayoritas mufasir menjelaskan bahwa nama hamba tersebut adalah Khidir. ${ }^{7}$ Namun nama aslinya menurut al-Zuhayli adalah Iliyā bin Malkān bin Qāligh bin Shālikh bin Arfakhshad bin Sām bin Nūh. Ia memiliki kunyah Abū al-'Abbās. Ayahnya adalah seorang raja dan ibunya bernama Alma, seorang putri ksatria (bint faris). ${ }^{-}$Ilmu laduni di dalam ayat ini maksudanya adalah ilmu hakikat, bukan ilmu syari'at. Dapat pula

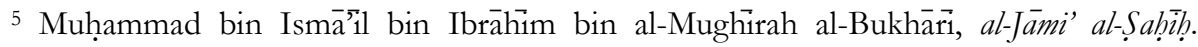
Kairo: Dār al-Shu'ab, t. th. Vol.1, 42. Nomor hadis 122. Wahbah bin Muștafa alZuhayli, al-Tafsir al-Munir fì al-'Aqïdah wa al-Shari'ah wa al-Manjah. Beirut: Dār al-Fikr alMa'așir, 2016, vol. 8, 317-318.

${ }^{6}$ Departemen Agama, al-Qur'an dan Terjemahnya. Surabaya: Pustaka Assalam, 2010, 412.

7 Abù al-Fidā' Ismāīil bin 'Umar bin Kathìr, Tafsìr al-Qur'an al-Ažim. Beirut: Dār Ṭaybah, 1999, vol. 5, 175; Mulā Huways 'Āli Ghāzi 'Abd al-Qādir, Bayān al-Ma'ànī. Damshiq: Maṭba'ah al-Tarāịi, 1382 H, vol. 4, 192; Abū Hayān al-Andalūsi, Tafsìr al-Baḅr al-Mubịt. Beirut: Dār al-Fikr, t. th. Vol. 6, 108; Shams al-Din Muhammad bin Ahmad alSharbini, Tafsì al-Siraj al-Munir. Beirut: Dār al-Kutub al-'Ilmiyah, t. th. Vol. 2, 307.

${ }^{8}$ Wahbah, al-Tafsir, vol. 8, 343. 
diterjemahkan dengan ilmu ghaib yang dapat meneropong kejadian masa depan. Apapun makna dari ayat ini, pada akhirnya akan berkesimpulan yang sama, yaitu nabi Khịiir mampu mengetahui 'rahasia langit' dan hal tersebut tidak dimiliki oleh nabi Mūsa.

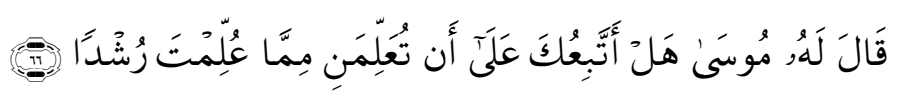

Mūsa berkata kepadanya (Khidir): "Bolehkah aku mengikutimu supaya kamu mengajarkan kepadaku ilmu yang benar di antara ilmu-ilmu yang telah diajarkan kepadamu?"

Pada ayat ini nabi Mūsa meminta izin supaya ia diperkenankan untuk berguru kepada nabi Khidir. Berdasarkan etika, seorang murid haruslah permisi terlebih dahulu kepada gurunya mengenai permintaan berbagai hal. Apalagi jika permintaan tersebut adalah sesuatu yang istimewa dan bersifat rahasia.

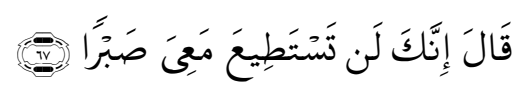

Dia menjawab: "Sesungguhnya kamu sekali-kali tidak akan sanggup sabar bersamaku.

Setelah nabi Mūsa meminta izin kepada nabi Khiḍir perihal ia akan berguru kepadanya tentang ilmu ghaib tersebut, nabi Khidir merasa ragu akan kesungguhan itu. Di dalam ayat ini seakan-akan Khiḍir sudah mengetahui akhir dari kisah ini, bahwa nanti nabi Mùsa tidak lulus uji. Signal yang memberikan kabar bahwa Khidir sudah mengerti hasil akhirnya adalah redaksi lan yang memiliki arti 'tidak akan'. Maksudnya adalah 'engkau tidak akan bersabar bersamaku'. Prediksi akhir dari Khidir ini sebenarnya telah dijelaskannya sejak awal dengan keterangan yang sangat rasional sebagai berikut:

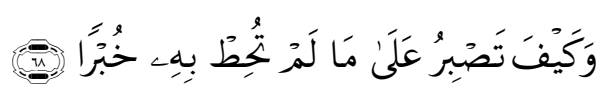

Bagaimana kamu dapat sabar atas sesuatu, yang kamu belum mempunyai pengetahuan yang cukup tentang hal itu?"

Sebelum jauh menjalani laku batin, sebenarnya nabi Müsa telah terlebih dahulu diberitahu oleh Khiḍir bahwa 'bagaimana mungkin kamu 
bisa bersabar atas perkara yang belum kamu ketahui sama sekali sebelumnya'? Maksudnya adalah perkara-perkara ghaib dan pengalaman spiritual yang belum pernah dialami oleh nabi Müsa. Oleh karena itu, ia menjelaskan di awal agar nabi Mūsa bersungguh-sungguh dalam menempuh laku batin. Di dalam istilah Jawa ungkapan seperti ini disebut dengan njampangi. Njampangi adalah ungkapan yang meremehkan, atau menganggap gagal peristiwa yang belum terjadi. Biasanya orang yang di jampangi akan lebih serius sehingga ia bisa berhasil. Perkara inilah yang ingin ditanamkan oleh Khidir kepada nabi Músa supaya dia benar-benar serius.

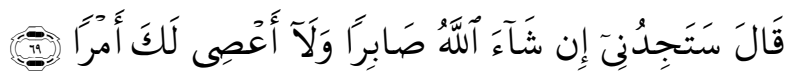

(Mūsa) berkata: "Inshā Allah kamu akan mendapati aku sebagai orang yang sabar, dan aku tidak akan menentangmu dalam sesuatu urusanpun".

Di dalam ayat ini nabi Müsa ingin meyakinkan Khiḍir yang awalnya meragukan keseriusannya untuk belajar ilmu ghaib. Mūsa cukup percaya diri dengan menyatakan bahwa ia akan bersabar dan tidak akan menentang apa yang telah diperintahkan oleh nabi Khiḍir. Setelah itu baru Khidir memberikan izin namun dengan satu syarat.

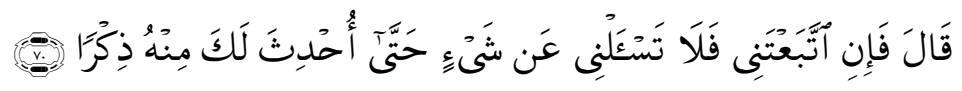

(Khidir) berkata: "Jika kamu mengikutiku, maka janganlah kamu menanyakan kepadaku tentang sesuatu apapun, sampai aku sendiri menerangkannya kepadamu".

Sepintas, syarat yang diajukan oleh Khiḍir terlihat sangat mudah, cukup dengan 'tidak bertanya', maka urusannya selesai. Syarat tidak bertanya ini hanya berlaku sampai nabi Khidir menjelaskan apa yang sebenarnya terjadi. Dalam spiritual Jawa, orang yang menahan sesuatu yang sebenarnya bisa dilakukan disebut dengan tarak. Jika ada orang yang tarak terhadap daging, maka dia tidak makan daging. Begitu juga dalam hal ini, nabi Mūsa dilarang untuk bertanya sampai pada waktunya diterangkan oleh Khiḍir. 


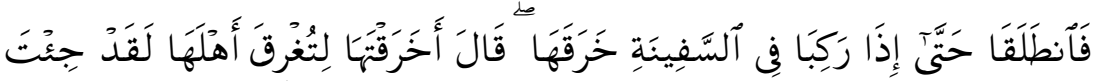

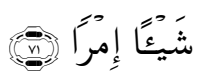

Maka berjalanlah keduanya, hingga tatkala keduanya menaiki perahu lalu Khiḍir melubanginya. Mūsa berkata: "Mengapa kamu melubangi perahu itu akibatnya kamu menenggelamkan penumpangnya?" Sesungguhnya kamu telah berbuat sesuatu kesalahan yang besar.

Nabi Khidir dan Müsa naik perahu itu dengan gratis, namun tidak disangka ternyata Khidir merusak papan dari perahu tersebut agar terlihat jelek dan berisiko bisa menenggelamkan seluruh muatan kapal. Atas perbuatan itu, spontan membuat Müsa berontak, sebab dibenaknya 'hanya orang yang tidak waras', tiba-tiba melubangi perahu yang ditumpanginya sendiri. Perbuatan tersebut tentu saja akan menenggelamkannya dan juga orang-orang yang ada di dalam perahu tersebut. Apa yang diprotes oleh nabi Mūsa memang masuk akal dan itulah barometer ilmu lahiriyah yang dimiliki Mūsa, bukan barometer ilmu ghaib.

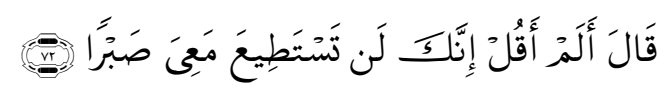

(Khidir) berkata: "Bukankah aku telah berkata: "Sesungguhnya kamu sekali-kali tidak akan sabar bersamaku".

Setelah nabi Mūsa menanyakan persoalan yang 'seharusnya dipertanyakan', ternyata dia lupa bahwa syarat mengikuti nabi Khiḍir adalah tidak bertanya. Kesalahan perdana ini kemudian langsung ditegur oleh Khiḍir dengan manyatakan 'bukankah aku sudah bilang engkau tidak akan mampu bersabar denganku?'. Ungkapan ini membuat kaget nabi Mūsa dan ia benar-benar khilaf.

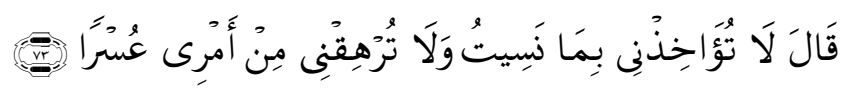

(Mūsa) berkata: "Janganlah kamu menghukum aku karena kelupaanku dan janganlah kamu membebani aku dengan sesuatu kesulitan dalam urusanku". 
Atas kekhilafan tersebut nabi Mūsa benar-benar minta maaf karena itu adalah sebuah kelupaan. Ia juga memohon agar tidak dihukum atas kesalahan itu dan ia juga memohon supaya urusannya dipermudah, tidak dipersulit. Atas permohonan itu, nabi Khị̣ir masih memaafkan meskipun secara literal al-Qur'an tidak menyebutkan 'kata maaf kepada Mūsa. Namun ketika laku batin yang dijalani oleh nabi Mūsa tersebut berlanjut, itu artinya pintu maaf secara otomatis masih terbuka.

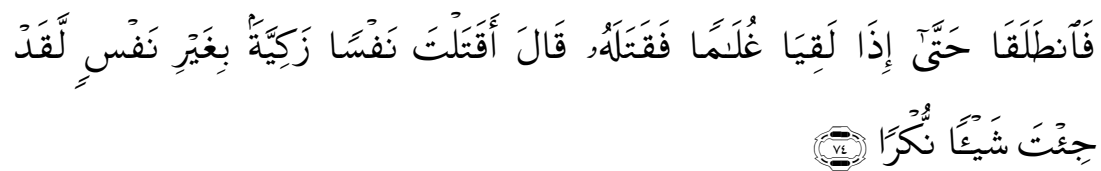

Maka berjalanlah keduanya; hingga tatkala keduanya berjumpa dengan seorang anak, maka (Khị̣ir) membunuhnya. Mūsa berkata: "Mengapa kamu membunuh jiwa yang suci, bukan karena dia membunuh orang lain? Sesungguhnya kamu telah melakukan suatu yang mungkar".

Kata nukran memiliki arti perkara yang ditolak oleh akal dan jiwa manusia. Bisa jadi, apa yang diucapkan oleh Mūsa saat itu - dalam redaksi orang Indonesia - "Ini gila". Anak kecil yang tidak salah apa-apa, tidak punya dosa apa-apa, lagi asyik bermain, tidak ada angin tidak ada hujan tiba-tiba dipotong lehernya oleh nabi Khidir. Sebagai manusia yang punya akal budi, perbuatan tersebut sungguh di luar dugaan Mūsa. Mungkin selain kata-kata kasar di atas, masih ada lagi kata yang bisa digunakan oleh orang awam, yaitu "kejam".

Biasanya, ketika seseorang berjalan-jalan dan berjumpa dengan anak kecil, bisa jadi yang dilakukan adalah sesekali ditemani bermain, di tanya dengan lembut, penuh kasih sayang, dan sebagainya. Saat itu tidaklah demikian, justru dibunuh. Hati nabi Mūsa sungguh tidak kuat menahan perbuatan yang tidak ber-prikemanusiaan itu. Ia kemudian protes untuk kedua kalinya atas perbuatan Khidir yang membunuh anak kecil tidak berdosa itu. Anak itu bernama Sham 'ùn atau Hāyshūr atau Haysūn. ${ }^{9}$

${ }_{9}^{9}$ Al-Zuhayli, al-Tafsìr, 343. 


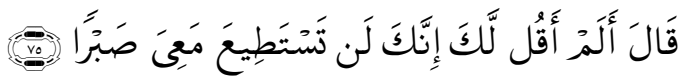

(Khidir) berkata: "Bukankah sudah kukatakan kepadamu, bahwa sesungguhnya kamu tidak akan dapat sabar bersamaku?"

Ayat 75 ini mirip dengan ayat 72 . Perbedaannya adalah di dalam ayat 75 ini memiliki redaksi tambahan kata laka (kepadamu). Penambahan kata ini memiliki fungsi penekanan kepada orang yang diajak bicara. Kalau di dalam ayat 72 menyebutkan 'bukankah aku telah berkata'. Namun di dalam ayat 75 ini menyebutkan 'bukankah aku telah berkata kepadamu'. Sosok Mūsa di dalam ayat ini dihadirkan sebagai penekanan sekaligus peringatan bahwa dia telah melanggar syarat berguru dan di awal juga telah disampaikan bahwa dia tidak akan bersabar. Pada akhirnya, Mūsa benar-benar melanggar syarat itu dan tidak lulus di tahap yang kedua ini.

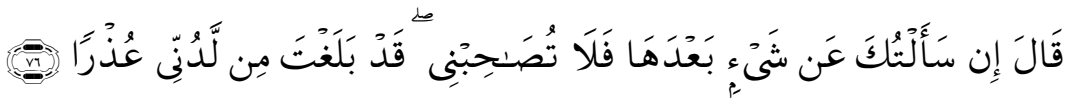

(Mūsa) berkata: "Jika aku bertanya kepadamu tentang sesuatu sesudah (kali) ini, maka janganlah kamu memperbolehkan aku menyertaimu, sesungguhnya kamu sudah cukup memberikan uzur padaku".

Di dalam ayat ke-76 ini tidak ada perkataan 'maaf' yang diucapkan oleh Mūsa. Bisa jadi, ia hanya menundukkan kepala dan terdiam atas kesalahan dia untuk kedua kalinya. Diamnya Mūsa tersebut memberikan isyarat bahwa dia benar-benar malu kepada Khiḍir atas kesalahan yang terulang kembali. Kemudian di dalam ayat ke-76 ini ganti Khiḍir yang berkata dengan nada 'ancaman' kepada Mūsa - mungkin karena kesal "Jika kamu menanyakan satu hal lagi kepadaku, maka cukuplah sampai di sini”. Mungkin itu redaksi percakapan biasa yang dapat digambarkan di dalam ayat ini. Pernyataan tersebut dikuatkan oleh Khidir bahwa dia sudah cukup untuk memberikan kesempatan kepada Mưsa agar tidak bertanya, namun hal itu kembali lagi terulang. 


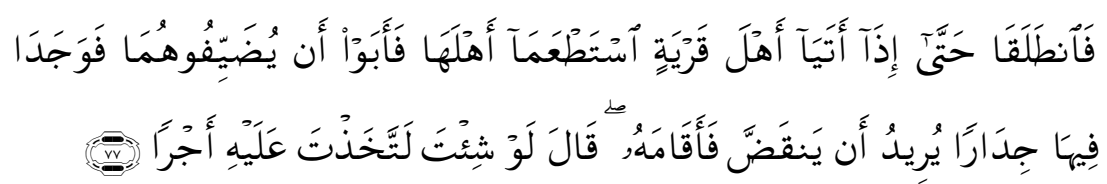

Maka keduanya berjalan; hingga tatkala keduanya sampai kepada penduduk suatu negeri, mereka minta dijamu kepada penduduk negeri itu, tetapi penduduk negeri itu tidak mau menjamu mereka, kemudian keduanya mendapatkan dalam negeri itu dinding rumah yang hampir roboh, maka Khidir menegakkan dinding itu. Müsa berkata: "Jikalau kamu mau, niscaya kamu mengambil upah untuk itu".

Setelah perjalanan panjang yang cukup melelahkan dialami oleh nabi Mùsa atas kesalahan-kesalahan yang dilakukannya, tibalah mereka berdua di sebuah desa atau kota bernama Anțākiyah. Di sana mereka berdua kelaparan dan kehausan lalu meminta makanan kepada penduduk negeri tersebut. Sesuatu yang tidak disangka ternyata terjadi, yaitu mereka berdua tidak dikasih makan. Padahal jika dilihat dari statusnya, nabi Mūsa adalah utusan Allah dan orang terpilih dari Bani Isrāil sedangkan nabi Khiḍir adalah orang yang terpilih dari kalangan ahli ilmu ghaib.

Setelah lelah, haus dan dahaga mereka tidak bisa dihilangkan, tibatiba mereka berdua melihat ada dinding yang akan roboh dan nabi Khidir mengajak nabi Mūsa untuk membangunnya. Di dalam ayat ini alQur'an menggunakan redaksi isti'arah pada kalimat yurid an yanqadda (ingin bangun). Padahal ayat ini membicarakan dinding, bukan manusia. Al-Qur'an menceritakan seolah-olah ada dinding yang memanggilmanggil layaknya manusia yang ingin dibangunkan dari kemiringannya. Saat itulah nabi Khidir mengajak nabi Mūsa untuk membangunnya.

Dengan nada santai nabi Mūsa menjawab "Jikalau kamu mau, niscaya kamu mengambil upah untuk itu". - dalam bahasa Jawa mungkin redaksinya begini - "kurangmen penggawean" (kog kurang pekerjaan). Nabi Müsa mengatakan demikian bukan tanpa alasan. Pertama, lelah, lapar dan dahaga yang ia rasakan tidak bisa hilang akibat tidak diberi makan oleh penduduk tersebut. Secara manusiawi, perasaan kesal kepada penduduk tersebut pasti ada. Kedua, tidak ada yang menyuruh untuk membangun 
tembok miring tersebut. Khiḍir justru mengajaknya untuk membangun. Satu menjadi 'kuli' dan satunya lagi menjadi 'tukang', begitulah mungkin pikiran orang Jawa di dalam memahami suatu ayat.

Di dalam tafsir al-Munir dijelaskan bahwa nabi Khidir membangun tembok itu dengan sekejap hanya dengan sekali sentuh. ${ }^{10}$ Namun jika diruntut dari alur ayat ini, kelihatannya, proses pembangunan tembok miring tersebut tidak sederhana. Jika memang hanya sekejap, nabi Músa bisa jadi tidak protes atas jerih-payah yang dilakukan oleh Khidir tersebut untuk meminta upah. Hal tersebut menandakan bahwa proses pembangunan tembok itu dilakukan dengan jerih-payah. Dengan demikian wajar apabila nabi Müsa menyindir Khiḍir, 'jika mau seharusnya mendapatkan upah'. Jika pembangunan tersebut terjadi dalam sekejap, kesan yang ditimbulkan adalah seperti memperlihatkan mukjizat nabi Khiḍir dihadapan Müsa secara langsung. Jika demikian yang terjadi, maka bisa jadi nabi Mūsa akan tersadar bahwa itu masih di dalam rangkaian laku batin yang dijalani.

Paling tidak ada tiga bentuk kekesalan yang dialami oleh nabi Mūsa dalam kesempatan kali ini. Pertama, kekesalan atas rasa haus dan dahaga. Kedua, meminta makanan penduduk tetapi tidak diberi dan yang ketiga adalah kejadian yang menggelitik pikirannya, yaitu tidak ada yang menyuruh dan tidak ada yang memberi upah untuk membangun tembok miring, malah dibangunnya. Sedangkan kekesalan yang terakhir adalah rumah tersebut berada di dalam kota yang penduduknya tidak memberikan jamuan saat diminta jamuan. Jadi, komentar Mūsa atas kejadian ini merupakan akumuliasi dari kekesalan-kekesalan kecil sehingga mencapai klimaksnya. Setelah kejadian menjengkelkan itulah nabi Khidir berkata:

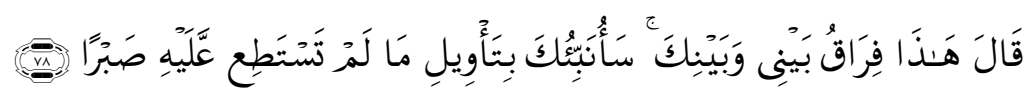

(Khidir) berkata: "Inilah perpisahan antara aku dengan kamu; kelak akan kuberitahukan kepadamu tujuan perbuatan-perbuatan yang kamu tidak dapat sabar terhadapnya.

${ }^{10}$ Wahbah, al-Tafsir al-Munir. al-Kahf [18]:77. 


\section{Berita Ghaib}

Apa yang dilakukan oleh Khiḍir sesungguhnya adalah keburukan. Namun di sisi lain, ada dua keburukan yang menjadi satu dan Khiḍir memilih keburukan yang paling kecil. Sedangkan keburukan yang lebih besar tidak diketahui oleh Mūsa, sebab ia hanya melihat yang tampak saat itu saja, bukan yang akan terjadi di kemudian hari. Oleh karena itu, dalam hal ini ada dua sudut pandang. Müsa melihat kejadian itu dari sisi logika manusia, nalar manusia atau mungkin lebih dekat dengan istilah empirisme-rasionalisme-syar'iyyah. Namun di sisi lain, nabi Khidir melihatnya dari sisi ilmu batin yang hakiki. Karena Mūsa belum bisa menerima kenyataan pada saat itu, maka Khidir menjelaskan hikmah di balik peristiwa yang terjadi sebagai berikut:

\section{Melubangi perahu}

Perahu yang dilubangi tersebut sesungguhnya milik orang miskin yang menggantungkan hidupnya dari perahu itu. Maksud nabi Khidir melubangi perahu itu agar perahu tersebut terlihat jelek. Sebab jika perahu tersebut kelihatan bagus, maka akan dirampas oleh seorang raja yang zalim. Raja tersebut hanya mau merampas perahu yang bagus-bagus. Nama raja tersebut adalah Hadad bin Badad. Di dalam Taurat disebutkan bahwa Badad adalah keturunan dari ${ }^{\top}$ Iṣ bin Ishạa ${ }^{11}$

Jika perahu rersebut dibiarkan seperti sediakala tanpa adanya lubang, maka perahu itu akan dirampas oleh penguasa zalim tersebut dan akibatnya si miskin pemilik perahu tadi akan kehilangan mata pencaharian untuk selama-lamanya. Kerusakan yang diakibatkan oleh lubang perahu jauh lebih kecil akibatnya dibandingkan dengan kehilangan perahu itu untuk salama-lamanya. Inilah ilmu batin yang dijelaskan oleh Khiḍir dan nabi Müsa tidak lulus dalam tahap laku batin yang pertama.

\section{Membunuh anak kecil}

Anak kecil yang dibunuh itu adalah anak yang berkulit putih dan berwajah tampan. Ia dibunuh oleh Khidir pada saat sedang asyik bermain

\footnotetext{
${ }^{11}$ Wahbah, al-Tafsir, vol. 8, 337.
} 
di pinggir pantai bersama teman-temannya. Mūsa dengan spontan memprotes atas kejadian itu sembari mengatakan 'mengapa engkau bunuh jiwa yang bersih, bukan karena dia membunub orang lain'. Protes nabi Mūsa ini kemudian di jawab pada lanjutan ayat 80-81: Anak yang dibunuh oleh Khidir tersebut kelak nanti akan menjadi kafir. Sedangkan orang tuanya mukmin. Karena kecintaan orang tua kepada anak tersebut, dikhawatirkan orang tuanya akan ikut kafir. Oleh karena itu Allah mengganti anak lain yang mukmin yang lebih baik, saleh dan berbakti kepada kedua orang tua.

\section{Membangun tembok rumah yang hampir roboh}

Rahasia batin tentang peristiwa membangun tembok yang hampir roboh tersebut ternayata di bawahnya terdapat harta benda milik anak yatim. Jika tembok tersebut menjadi roboh, maka harta simpanan yang berada di bawah tembok itu dikahawatirkan akan kelihatan dan dijarah orang lain. Allah hendak menyelamatkan harta benda tersebut kepada yang berhak memilikinya, yaitu anak yatim yang belum mengerti apa-apa. Kelak ketika mereka sudah dewasa, mereka bisa menggunakan harta simpanan itu untuk kebutuhan hidupnya.

\section{Pesan Terakhir Khiḍir}

Meskipun dalam laku batin tersebut nabi Mūsa dinyatakan tidak lulus, namun menjelang perpisahan mereka, nabi Mūsa meminta saran dan nabi Khidir-pun memberikan saran yang sangat menyentuh hati. Khị̣ir berkata:

$$
\text { كن بسّاما ولا تكن ضحّاكا، ودع اللجاجة، ولا تمش في غير حاجة، ولا }
$$

'Jadilah orang yang murah senyum, bukan orang yang banyak tertawa. Tinggalkanlah sikap keras kepala, jangan berjalan untuk perkara yang tidak berguna, jangan mencela orang-orang yang banyak berbuat dosa karena kesalahan mereka dan tangisilah kesalahanmu wahai Ibnu 'Imrān'. 
Pesan terakhir Khiḍir ini setidaknya memberiken pelajaran berharga kepada nabi Mūsa. Pertama, agar murah senyum, bukan tertawa. Hal ini menandakan sikap seorang yang lemah lembut, sebab konon nabi Mūsa adalah orang yang keras dan temperament. Kedua, supaya meninggalkan sikap yang keras kepala. Maksudnya adalah agar mempertimbangkan usulan orang lain, jangan bersikeras atas ego senidiri. Perjalanan singkat itu membuat nabi Müsa terkesan gembrusu (tergesagesa) dengan sikap kritisnya sehingga lupa syarat menuntut ilmu pada saat itu adalah 'jangan bertanya'.

Ketiga, jangan berjalan untuk perkara yang tidak berguna. Pesan ini memberikan pelajaran bahwa nabi Müsa seyogyanya bersabar terlebih dahulu supaya perjalanan spiritualnya membuahkan hasil, bukan seperti saat itu 'yang sia-sia'. Keempat, jangan mencela orang yang berbuat dosa karena kesalahan mereka. Pesan ini memberikan teguran kepada Mūsa bahwa selama ini dia adalah orang 'yang paling mengerti dan paling benar'. Ia lupa di luar sana masih banyak rahasia ilahi yang tidak dia ketahui. Kelima, tangisilah kesalahanmu wahai Ibnu 'Imrān adalah sebuah pesan agar nabi Müsa bertobat atas kesalahannya dan jangan lagi mengulang kesalahan yang sama di kemudian hari, meskipun kesempatan itu tidak datang dua kali.

\section{Pesan moral}

Barometer ilmu syari'at dengan ilmu hakikat/ma'rifat berbeda. Cover dan isi tidak selalu sama. Ilmu bisa dicari melalui internet, membaca, belajar dan sekolah. Sedangkan laku batin hanya berlaku bagi orang-orang khusus yang mampu dan diberi kashf oleh Allah swt. Allah menyembunyikan identitas orang istimewa tersebut, karena biasanya orang yang ahli dalam bidang ilmu batin, tidak ingin viral. Müsa hanya menguasai ilmu syari'ah, bukan ilmu hakikat. Ilmu syari'ah diberikan kepada orang terpilih secara terang-terangan. Sedangkan ilmu hakikat diberikan kepada orang terpilih dan bersifat rahasia. 
Spiritualis, vol. 5, no. 2, September 2019|222

\section{Kesimpulan}

Perjalanan spiritual yang dilakukan oleh nabi Müsa dengan Khidir merupakan salah satu bukti bahwa cara pandang terhadap dunia ini memiliki sudut keberaran masing-masing. Nabi Mūsa memandang perahu yang dilubangi oleh penumpangnya sendiri (Khidir) dianggap sebagai tindakan yang irrasional. Nabi Khidir yang membunuh anak laki-laki tidak berdosa dipandang sebagai tindakan kejam, tidak manusiawi. Nabi Khidir yang membangun tembok miring tak bertuan, tanpa ada yang menyuruh dan tanpa upah dianggap sebagai 'kurang kerjaan'. Itu semua adalah cara pandang Müsa yang masih di level syariat.

Semua kejadian yang dilakukan oleh Khidir tersebut merupakan perintah Allah dan ada hikmah di balik semua itu. Dalam laku batin ini nabi Müsa tidak lulus uji karena dia melanggar persyaratan yang telah disepakai sebelumnya, yaitu tidak boleh bertanya tentang apapun yang dilakukan oleh Khiḍir selama belum diterangkan hakikat dari peristiwa itu. Pelanggaran pertama dan kedua masih ditolerir, namun pelanggaran yang ketiga sudah tidak ada lagi kata maaf. Mūsa harus merelakan bahwa perjalanan spiritualnya gagal.

Perahu yang dilubangi itu milik orang miskin yang akan dirampas oleh penguasa zalim. Jika dilubangi, maka perahu tersebut tampak jelek dan tidak akan dirampas, sebab yang dirampas adalah yang bagus-bagus. Anak yang dibunuh oleh Khidir itu kelak bisa menjadikan orang tuanya kafir jika tidak dibunuh. Tuhan ingin menggantikannya dengan anak lain yang lebih saleh dan berbakti kepada orang tua. Tembok miring yang dibangunkan kembali oleh Khidir itu milik anak yatim. Di dalamnya ada harta simpanan yang dapat diambil saat ia dewasa. Jika tembok tersebut roboh, maka harta simpanan itu akan kelihatan dan akan diambil orang. 
Spiritualis, vol. 5, no. 2, September 2019|223

\section{DAFTAR PUSTAKA}

'Abd al-Qādir, Mulā Huways 'Āli Ghāzi. Bayān al-Ma'āni. Damshiq: Maṭba'ah al-Tarāài, $1382 \mathrm{H}$.

Abū Ḥayān al-Andalūsi, Tafsìr al-Baḥr al-Muḥit. Beirut: Dār al-Fikr, t. th.

Bukhāri (al), Muhammad bin Ismā̄ill bin Ibrāhīm bin al-Mughïrah. alJami' al-Sahị̄h. Kairo: Dār al-Shu'ab, t. th.

Departemen Agama, al-Qur'an dan Terjemahnya. Surabaya: Pustaka Assalam, 2010.

Ibn Kathīr, Abū al-Fidā' Ismāīil bin 'Umar. Tafsìr al-Qur'ān al-Ažìm. Beirut: Dār Taybah, 1999.

Sharbinī (al), Shams al-Din Muḥammad bin Aḥmad. Tafsì al-Siraj alMunìr. Beirut: Dār al-Kutub al-'Ilmìiah, t. th.

Suhardi, Manekung di Puncak Gunung: Jalan Keselamatan Kejawen. Yogyakarta: Gajah Mada University Press, 2018.

Tim Pusat Bahasa Departemen Pendidikan Nasional, Kamus Bahasa Indonesia. Jakarta: Pusat Bahasa, 2008.

Zuhayli (al), Wahbah bin Muștafa. al-Tafsir al-Munir fí al-'Aqïdah wa alShari'ah wa al-Manjah. Beirut: Dār al-Fikr al-Ma'àsir, 2016. 